\title{
CERCETARRI FOLCLORICE
}

CZU: 392.8

https://doi.org/10.52505/llf.2021.2.08

\section{MÂNCAREA ÎNTRE VITAL ȘI CULTURAL}

\author{
Tatiana POTÎNG \\ Institutul de Filologie Română „Bogdan P.-Hasdeu” \\ ORCID: https://orcid.org/https:// 0000-0002-5944-3426
}

Rezumat: Deși multă vreme ignorată ca fiind minoră, cultura culinară contribuie în mod esențial la creionarea profilului identitar al unui individ, al unei comunități sau a unei culturi.

Identitatea culturală își găsește expresie nu atât în conținutul mâncării, cât mai ales în specificul procesării bucatelor, modul în care se ia masa, timpul și locul în care se pregătește. Componenta culturală a alimentației la etapele de dobândire, cultivare, preparare și consum a hranei este confirmată prin numeroase prescripții și norme care asigură buna organizare și functionare a existenței umane.

În acest articol ne propunem să analizăm formele în care imaginarul popular atribuie hranei o valență sacră, capabilă să influențeze sănătatea și viața omului în cele mai timpurii culegeri folclorice românești de credințe și superstiții.

Cuvinte-cheie: marcher cultural, post, masă rituală, tabu alimentar, ospăț.

Abstract: Although long overlooked as a minor issue, culinary culture makes an essential contribution to shaping the identity profile of an individual, a community or a culture. Cultural identity finds expression not so much in the content of the food, but in the specifics of how the food is processed, how it is eaten, when and where it is prepared.

The cultural component of food at the stages of acquiring, growing, preparation and consumption of food is confirmed by numerous prescriptions and rules that ensure the proper organisation and functioning of human existence.

In this article we aim to analyze the forms in which the popular imagination attributes to food a sacred valence, capable of influencing human health and life in the earliest Romanian folklore collections of beliefs and superstitions.

Keywords: cultural indicator, fasting, ritual meal, food taboo, feast.

Mâncarea nu a fost niciodată doar alimentație, căci bucătăria oricărei țări este legată organic de cultura și istoria acesteia. S-a subliniat deseori că bucătăria este mai conservatoare decât religia, limba sau orice alt aspect cultural, deoarece anumite elemente fundamentale rămân rezistente la cuceriri, procese de migrație, colonizare sau schimbări sociale și tehnologice. Acest lucru se datorează faptului că atitudinile noastre față de hrană sunt învățate și insuflate emoțional, ceea ce îi conferă un efect deosebit de îndelungat.

Deși, din punct de vedere biologic, alimentația este vitală pentru supraviețuire, mâncarea este mai mult decât o sursă de energie pentru om, deoarece 
implică toate cele cinci simțuri care trimit invariabil la o experiența culturală, la valori și practici sociale.

În această privință Roland Barthes afirma că „hrana asigură o continuitate a naţiunii, o ființare alimentară, constituind astfel o memorie, o istorie în viața modernă”, (1961 ...)în timp ce Léo Moulin sublinia funcția identitară a mâncării, care, dincolo de a sătura, definește și leagă oamenii:„,noi nu mâncăm cu dinții și nici nu digerăm cu stomacul; noi mâncăm cu spiritul, gustăm după niște norme culturale ce sunt legate de sistemul de schimburi reciproce care se află la baza întregii vieți sociale. De aceea, fiecare popor se definește prin practicile sale alimentare și prin obiceiurile sale la masă, la fel de bine cum se definește prin limba sa, prin credințele sau practicile sale sociale". (1975, p. 63)

Așadar, consumul hranei este comun pentru toți, dar circumstanțele în care se mănâncă, modul, locul, cauza consumului sunt marcate de profunde diferențe culturale și istorice.

Din cele mai vechi timpuri alimentele au trasat granițe naționale și regionale și au devenit simboluri pentru diferite identități naționale. Aducând în scenă valorile și practicile culturale, mâncarea devine un puternic marker identitar, definind personalitatea, clasele sociale, stilurile de viață, rolurile și relațiile de gen din cadrul familiei, grupului etnic sau națiunii.

Prin prezentul demers ne propunem să determinăm în ce măsură mâncarea devine un indicator cultural al identității naționale și să analizăm percepția populară asupra consumului hranei, reflectată în culegerile populare. Pentru argumentarea teoretică a cercetării am apelat la studiile consacrate din domeniul antropologiei alimentației, etnologiei și folcloristicii.

Alimentația și practicile culinare au devenit subiect de analiză sociologică, antropologică, etnologică, literară, abia în primele decenii ale secolului trecut. Primele studii (Audrey Richards, 1932) din domeniul antropologiei culturale au consemnat relația gastronomiei cu ciclurile vieții și relațiile interumane și au trasat calea pentru cercetări ulterioare. Interesul pentru fenomenul alimentației ca fapt cultural a crescut odată cu studiile structuraliștilor (Claude Lévi-Strauss, Mary Duglas), care au încercat să înțeleagă faptul că gustul este construit cultural și controlat social.

Un moment de cotitură în cercetarea antropologiei bioculturale a alimentației l-a constituit studiul transdisciplinar al lui Claude Fischler cu privire la "principiul încorporării” alimentației într-un sistem cultural. Autorul susține că imaginarul alimentar este determinant pentru definirea sentimentului iden- 
titar, iar valorile, credințele si practicile sociale influențează ceea ce mănâncă și ceea ce gândesc oamenii despre mâncare. (1988, p. 119)

În fond, identitatea culturală își găsește expresie nu atât în conținutul mâncării, cât mai ales în specificul procesării bucatelor, modul în care se ia masa, timpul și locul în care se pregătește. Fiecare din aceste aspecte și momente sunt normate prin obiceiuri, tradiții, credințe și superstiții populare. Identitatea culturală a fiecărui popor este, în mare măsură exprimată în modelul său alimentar, în normele comportamentale în legătură cu procesul gătitului și al consumului hranei, în interdicțiile în privința unor alimente sau produse.

Conform ultimelor studii din spațiul sociocultural românesc „alimentația devine un factor major de marcare a identității culturale, ,fiind chiar nucleul procesului de construcție identitară”. Drept confirmare „anumite alimente sunt considerate mâncare naţională, simboluri ale identității naționale”, iar „hrana strămoșilor este un fundament al identității unui grup social, bucătăriile regionale constituie o reprezentare simbolică a națiunii sau identității naționale, în dorința afirmării continuității istorice și a unei apartenențe comune.” (Marinescu, 2016, p. 120)

În viziunea redutabilului etnolog român Ofelia Văduva, identitatea gastronomică românească derivă din caracteristicile etnopsihologice și din matricea culturală a poporului, iar "respectarea numeroaselor zile de post, a tabuurilor și prohibițiilor alimentare, utilizarea unor alimente cu rol ritual”, dovedesc „potențialul creator românesc" și pot fi considerate adevărate chei pentru „descifrarea profilului identitar românesc.” (2011, p. 5) Această bază identitară conține o serie de indicatori specifici ce țin de spațiul social alimentar: gusturile, obiceiurile și regulile la masă, legile ospitalității, modurile de preparare a hranei, distribuirea sarcinilor în bucătărie, respectarea sau refuzul prescripțiilor religioase culinare ș.a.

Markerii gastronomici ai imaginarului colectiv și-au găsit o reflectare generoasă în culegerile de credințe și superstiții populare românești de la începutul secolului trecut. Volumele Datinile și credințele poporului român de Elena Niculiță-Voronca, Credinţi și superstiţii ale poporului român de Artur Gorovei au conservat percepția poporului în legătura cu consumul hranei, constituind o sursă inestimabilă în studiul valorii simbolice și culturale a alimentaţiei pentru poporul român.

Așa cum putem deduce din consemnările folcloriștilor, în spațiul etnocultural românesc masa, departe de a fi doar atribut de mobilier, este un spațiu sacru care se cere a sta la loc de cinste sub icoane, la răsărit. Masa trebuie să 
fie acoperită cu față de masă albă și pe masă să stea pâine și sare, să nu fie goală. (Voronca, p. 205)

În corelație cu simbolistica sacră a mesei, consumul hranei este ridicat la nivel de ritual cotidian care nu se poate produce decât în condițiile și în locul prestabilit: Omul totdeauna pe masă să cuvine să mănânce, nu în alt loc, pe laiță sau unde apucă, căci pentru aceea i-a dat Dumnezeu masa. A sfida sau desconsidera normele rituale și a te așeza pe masă e păcat, nici coatele să nu le pui pe masă când mănânci, căci zice că șezi ca câinii pe brânci.

Procesul profan al consumului hranei poate ieși din contingența biologică prin identificarea cu ritualul statului la masă. Mâncatul, prin obiceiurile mesei, din acțiune banală, specifică tuturor ființelor vii, se „umanizează” devenind act cultural. De aceea, norma comportamentală folclorică prevede că $n u-i$ bine să zici: "mâncăm” sau "mănânc", căci te mănânci în sine; să mănâncă, se sfădesc cei de casă, e huit, foc în casă. Dar zici: „Stăm la masă”, „ospătăm.” (Voronca, p. 207)

În mare parte, prevederile protocolare în legătura cu procesul consumului hranei, sunt norme generale de conduită, valabile până în prezent:

Când mănânci cu pălăria sau căciula pe cap atunci dracul râde și Dumnezeu plânge. (Gorovei, p. 145)

La mâncare să nu stai în picioare, ci șezând să mănânci, căci Domnul Christos a șezut la masă și tot astfel trebuie să facem și noi. (Voronca, p. 206)

Omul totdeauna să fie cumpătat la masă, să nu mănânce prea mult, căci e păcat. Când să scoală, să nu fie prea sătul. (Voronca, p. 206)

„Din tot ce-i mânca, să rămâie o bucățică, căci de mănânci tot, Maica Domnului plânge și zice: „Iaca a mâncat totul!” (Voronca, p. 208)

În pofida caracterului banal evident, aceste norme comportamentale sunt pronunțat influențate atât de morala creștină, cât și de religia populară în care divinității i se atribuie trăsături omenești, de supraveghetor al meselor noastre.

Interesul Elenei Niculiță-Voronca pentru componenta normativă a culturii alimentației devine pregnant în subcapitolul Cum să nu mănânci din celebra culegere, în care este consemnat cadrul limitativ pentru consumul hranei în imaginarul popular. Aici, cele mai multe interdicții vizează spațiul impur și neconform pentru a mânca. Astfel, conform credințelor populare, NU SE POATE să mănânci din vatră, că-ți moare mama, îi mănânci puterea; să mănânci din oală, că plângi sau ai vreme rea la nuntă; să mănânci c-o coadă împletită și una despletită, că rămâi vadană, să mănânci când te piepteni, că-ți mănânci viața, mori. (Voronca, p. 206) Observăm că în anumite cazuri 
judecata populară este intransigentă cu potențialii infractori, iar sancțiunile sunt evident asimetrice în raport cu gravitatea faptei.

Foarte multe dintre prescripțiile menționate în culegerile folclorice interzic cumularea mâncatului cu alte activităţi, cum ar fi cititul, mersul la fântână, lucrul în grădină, etc., evidențiindu-se astfel valența simbolică a alimentaţiei pentru ființa umană. Unele tabuuri alimentare din cele analizate cuceresc mai ales prin capacitatea creatoare de comparație a imaginarului popular: Prin grădină să nu mănânci sau pe drum mergând, că plânge Maica Domnului și blastămă să fii ca vita, să tot rugumi și saț să nu mai ai. (Voronca, p. 191)

Credințele referitoare la locul interzis mâncatului sunt foarte variate, cuprinzând toată gospodăria și activitățile țăranului. Astfel: De pe brațe să nu mănânci, că-ți mănânci dragostele și norocul. Din poale să nu mănânci, că-ți mănânci dragostea; Cuprinsă pe după horn să nu mănânci că nu te măriți etc. (Voronca, p. 206)

Cea mai frecventă interdicție vizează mâncatul pe prag. Simbolistica nefastă a pragului ca spațiu de limită între pur și impur între sacru și profan își găsește reflectare în superstițiile negative care prevestesc necazuri pentru cei care le ignoră: Fata ce mănîncă pe prag nu se poate mărita și chiar oricine să nu mănânce pe prag, că-și mănâncă norocul. (Voronca, p. 205) Încălcarea interdicției pragului se poate solda cu „despărțitul de bărbat”, poate aduce foamea, sau provoca nebunia.

În privința timpului recomandat, dar, mai ales, interzis pentru consumul hranei situația este diferită, cele mai multe tabuuri alimentare fiind legate de perioada postului care premerge fastului sărbătorii, și se caracterizează, în primul rând, prin abstinență: În ziua de Ajun nici pește nu se mănâncă, pentru că e cu sânge. Nu se mănâncă nimic ce e cu sânge, pentru că Maica Domnului a fost plină de sânge. Să mănâncă numai cât aceea ce rodește pământul: bob, bureți, etc. (Voronca, p. 59) Respectarea tabuurilor alimentare din această perioada constituia una din principala condiție de acces către timpul sacru.

Referitor la natura specifică a postului Emile Durkheim consideră că acesta, prin ricoșeu, exercită asupra individului o acțiune pozitivă. Din cauza barierei care separă sacrul de profan, „omul nu poate întreține raporturi intime cu lucrurile sacre decât cu condiția de a renunța la tot ce este profan în el însuși. Nu poate duce o viață religioasă cât de cât intensă decât dacă se retrage într-o măsură mai mare sau mai mică din viața cotidiană." (1995, p. 284) Postul reprezintă deci, într-un anume sens, condiția de acces către sacru. Interdicțiile postului nu se limitează la a proteja ființele sacre de contactele 
vulgare, ci acționează asupra credinciosului însuși, a cărui stare o modifică în sens pozitiv. Cel care s-a supus ascetismului nu mai este cel care era înainte. În această perspectivă Durkheim explică esența postului drept abținere de la un lucru util corespunzător necesităţilor umane cotidiene. Ascetismul bazat pe abstinență severă de la activitățile profane este condiția de accedere către sacralitate. „Ascetul pur este un om care se ridică deasupra oamenilor și care dobândește o sfințenie deosebită prin post, veghe, recluziune și tăcere, într-un cuvânt prin privațiuni, și nu prin acte de pietate pozitivă (ofrande, sacrificii, rugăciuni. etc.)”. (1995, p. 287)

În culegerea Elenei Niculiță-Voronca se consemnează în repetate rânduri importanța postului pentru existența țăranului român: Posturele însamnă mare lucru înaintea lui Dumnezeu. Cine postește mare dar își câștigă și sunt de mare ajutor"; Cu postul, cu rugăciunele și cu faptele cele bune să capătă împărățtia ceriului. (Voronca, p. 234) În contradicție cu declarațiile informatorilor din capitolul rezervat postului, cu privire la valoarea spirituală și importanța purificatoare a abstinenței: În postul cel mare să abțin de la orice petreceri, să abțin de la cântec; numai a cânta din fluier, zice că nu e păcat. (Voronca, p. 233) Foarte multe credințe și superstiții din culegere atribuie postului funcții practice. Postul se recomandă a se ține pentru roadă, pentru măritat, pentru noroc, pentru dușmani, sau ca să nu mănânce vrăbiile semințele de pe lan. Ca și în cazul altor interdicții magice, funcția postului, în imaginarul popular, în cele mai multe cazuri, este utilitar-practică și social-culturală.

În cultura populară românească tabuurile alimentare celei mai persistente în timp vizează femeia în stare de „dar”. Interdicțiile alimentare din perioada sarcinii femeii sunt dictate de pericolul transferului anumitor caracteristici ale alimentelor asupra copilului. Se crede, astfel, că ingurgitarea hranei care și-a pierdut integritatea poate duce la apariția semnelor din născare, iar consumul poamelor crude, poate provoca nașterea înainte de termen. Consumul de fructe păstăioase în zi de duminică, poate duce la nașterea unui copil „bolând și tâmp la minte”, de „carne netăiată din frigare” poate provoca „limba prinsă”, a „borșului umplut în zi de sec”, apariția unui fel de „bubișoare numite focuri.” (Gorovei, p. 235, 236) Același principiu al analogiei stă la baza interdicției consumului de pești și melci, „că vor naște copii băloși și mucoși”, a aripilor de la pasăre, „ca să nu facă copilul boala aripilor”, (Gorovei, p. 235) Capacitatea imaginarului colectiv de a proiecta similitudini este de-a dreptul uluitoare. Astfel, în anumite zone, se credea că gravida nu trebuie să mănânce carne de capră, pentru a nu se sclinti picioarele copilului, carne de iepure, ca să nu doar- 
mă copilul cu ochii deschiși, sau ciuperci, ca să nu aibă copilul pistrui pe față. (Hulubaș, p. 26) Este de remarcat că principiul corespondenței funcționează nu doar în relaționarea cu aspectul animalului, sau a produsului consumat, ci și cu procesul mâncatului, relevat în interdicția de a mânca din polonic, „ca să nu aibă pruncul gura largă”. (Gorovei, p. 241)

Credințele populare în legătură cu procesul alimentar vizează și dimensiunea etică a existenței relevând principalele calități umane apreciate de mentalul popular: ospitalitatea, generozitatea și credința. Când mănânci ceva și-ți cere cineva, să nu-i zici doară „na” și să nu-i dai, căci de-l minți, atunci îți minți pe cei de-i ai morți; Când vine cineva și te găsește la masă să-l chemi că-i mânat de Dumnezeu. (Gorovei, p. 141)

Prescripțiile populare în legătură cu hrana dezaprobă excesul și condamnă furtișagul în cele mai variate forme: Se crede că acel om care mănâncă mult este egoist;Poporul crede că este iertat a mânca dintr-o grădină sau vie, poame sau struguri pentru a-și astâmpăra pofta gurii, a lua însă din ele și acasă se ține de furt; Pasere, vita rătăcită nu se mănâncă, că pățești ca Arie (capeți pânticărie mare).

Ospitalitatea poporului român își găsește reflectare, de asemenea, în numeroase credințe și superstiții ce vizează pâinea și sarea, alimentele cu o profundă încărcătură simbolică: „Sare e tare păcat a fura, că ea una cu pâinea merge. Dacă furi sare nu e bine în casă, căci sarea nu poate fără pâine și pâinea fără sare; Ca pâinea și sarea nu-i alta în lume, care să pedepsească pe cel vinovat, pe cel nevinovat, $n u$. Legenda spune că simbolul alăturării pâinii cu sarea este străvechi și trimite la ivirea Pământului de sub apele sărate, care mai apoi a rodit pentru oameni. De aceea, darul cel mai de preț oferit în semn de pace și prietenie oaspeților este pâinea rotundă și sarea.

Luate separat, pâinea și sarea rămân elemente pline de semnificație cu rol distinctiv în angrenajul credințelor populare. Sarea a fost încă de la începuturile omenirii tratată ca un lucru prețios și obținut prin trudă grea. În concepția populară Sarea e mana lui Dumnezeu. Sarea e dreptatea. Sfânta sare e sfânta dreptate.

De cealaltă parte, pâinea e hrana primordială a omului și rodul muncii lui. În ritualurile religioase, pâinea are rol sacru, iar în traiul de zi cu zi, exprimă două concepte umane: muncă și iubire. În acest sens Varvara Buzilă susține că prin „pâine” are loc o reintegrare a sacrului în viața omului, iar alegerea pâinii în calitate de produs cheie cu funcție în desfășurarea riturilor este rezultatul unui proces de lungă durată de instrumentalizare simbolică, prin sincronizarea 
căruia se menține continuitatea culturii populare.

Este de remarcat că poporul român dezvoltă un adevărat cult al pâinii considerându-se că: pâinea nu trebuie să steie cu fața în jos, că e mare păcat; casa să vezi că arde, să nu ieși până nu vei întoarce pâinea ca să steie așa cum trebuie.

Pâinea să n-o calci în picioare, că e păcat. Fărmăturele nu se scutură pe unde îmblă oamenii, dar în lături undeva. O bucãțicã de pâine dacă cade, omul o râdică și o sărută ș-o pune înapoi pe masã, cãci, dacã faci batjocură de pâine, te bate și ea, cã n-o ai. În drum dacă gãsești o bucãțică de pâine, sã o rãdici și sã o pui undeva sus, deoparte s-o mãnânce vro pasãre. (Voronca, p. 233)

\section{Concluzie}

În concluzie, analizând datele oferite de textele din culegerile de credințe și superstiții populare, putem afirma că procesul de alimentare și hrănire nu se rezumă doar la caracterul biologic, fiind din această perspectivă, un generator de energie vitală, ci, în cazul oamenilor, reflectă întotdeauna și complexe valori identitare. Ca parte integrantă a culturii, mâncarea spune multe despre specificul unui popor, despre istoria și originile lui, despre contactele, schimburile culturale și interferențele de-a lungul timpului. În cadrul acestei cercetări am constatat că imaginarul colectiv, exprimat în credințe și superstiții reflectă respectul poporului român pentru actul alimentar și pentru hrană ca dar de la Dumnezeu.

\section{Referințe bibliografice:}

1 BARTHES, Roland. Pour une psycho-sociologie de l'alimentation contemporaine, Annales. Economies, Societés, Civilisations, Volume 16, Issue 5, 1961.

2 BUZILĂ, Varvara. Pâinea: Aliment și Simbol. Experiența sacrului. Chișinău: Ed. Știința, 1999.

3 CIAUȘANU, Gh. F. Superstițiile poporului roman în asemănare cu ale altor popoare vechi și noi, Ediție critică, prefață și indice tematic de I. OPRISAN. București:Ed. Saeculum I.O, 2013.

4 DURKHEIM, E. Formele elementare ale vieții religioase, trad. rom., M. Jeanrenaud și Silviu Lupescu, pref. Gilles Ferreol. Iași: Polirom, 1995.

5 FISCHLER, Claude. Food, self and identity. În: Social Science Information, 27, (2) 1988, p. 275-292.

6 GOROVEI, Artur. Credinți și superstiții ale poporului român. București: Editura Grai și suflet - Cultura națională, 1995.

7 HULUBAȘ, Adina. Obiceiuri de naștere din Moldova: tipologie și corpus de texte. Iași: Editura Universităţii „Al. I. Cuza”, 2012.

8 LÉVI-STRAUSS, Claude. Antropologia structurală. București: Editura Politică.

9 MARINESCU, Angelica Helena. Sociologia alimentației. Teorii, perspective și tendințe 
contemporane, B., Tritonic, 2016.

10 MOULIN, Léo, L'Europe à table, introduction à une psychologie des pratiques alimentaires. Bruxelles: Elsevier Séquoia, 1975.

11 NICULIȚĂ-VORONCA Elena. Datinile și credințele poporului român adunate și așezate în ordine mitologică. Iași: Editura Polirom, 1998.

12 VĂDUVA, Ofelia. Pași spre sacru. Din etnologia alimentației românești. București: Editura Etnologică, 2011.

13 ЭВАНС-ПРИЧАРД, Э. История антропологической мысли. Москва: издательская фирма «Восточная литература» РАН, 2003.

Notă: Articolul a fost realizat în cadrul proiectului de cercetare 20.80009.1606.03 Contexte socio-culturale autohtone și interconexiuni europene în creația populară și literatura cultă din Basarabia (sec. XIX până în prezent), Institutul de Filologie Română „Bogdan Petriceicu-Hasdeu” al MECC. 